\title{
Study The Effects Of Corporate Image, Service Quality And Price Perceptions On Customer Satisfaction And Purchase Loyalty (A Survey On Pertamina In South Sulawesi Province)
}

\author{
Paulus Johan Lolo
}

\begin{abstract}
This study seeks to analyze the influence of corporate image, quality services and price perceptions of Pertamina product customer satisfaction, analyze the influence of corporate image, service quality and price perceptions on purchase loyalty, analyze customer satisfaction on purchase loyalty, and analyze the influence of corporate image, service quality and price perception through customer satisfaction on purchase loyalty. The study was conducted at the Pertamina Office in South Sulawesi Province with a population of 5,540 people and a sample of 277 respondents based on a 5\% Quota sampling method. Data were analyzed using the Structural Equation Model using AMOS 18. The results found that corporate image, service quality and price perception had a positive and significant effect on customer satisfaction. Corporate image, service quality and price perception have a positive and significant effect on purchase loyalty. Customer satisfaction has a positive and significant effect on purchase loyalty. Feelings of pleasure using the product as an actualization of the attitude of customer loyalty, corporate image and service quality through customer satisfaction has a positive and significant effect on purchase loyalty, while price perception through customer satisfaction has a positive and insignificant effect on purchase loyalty.
\end{abstract}

Index Terms - Corporate image, service quality, price perception, satisfaction, purchase loyalty.

\section{INTRODUCTION}

Pertamina as a state-owned company (BUMN) has a superior vision, mission and value system of 6C (consisting of; Clean, Competitive, Confident, Customer Focus, Commercial and Capable). Pertamina's vision "To Be A World Class National Energy Company", by developing the mission " To Carry Out Integrated Core Business in Oil, Gas, New and Renewable Energy Base On Strong Commercial Principles".

The 6C superior values that are applied Facing competition in the era of the industrial revolution 4.0, Pertamina is trying to be able to compete in a healthy and superior manner by marketing retail BBM (fuel oil) products for the transportation, household and fishermen sectors through SPBU (Public Filling Station) the largest in all of Indonesia. At present Pertamina has marketed gasoline and gasoline engine diesel fuel products. For petrol-engined BBM products, there are Pertamax Racing, Pertamax Turbo, Pertamax, Pertalite and Premium products. Whereas diesel engines sell Pertamina Dex, Dexlite and Solar products.

The marketing of BBM products has become a politically

Published on March 2, 2020

Paulus Johan Lolo, Hasanuddin University, Makassar, Indonesia.

(e-mail: pdjohanlolo63@gmail.com). charged competitive economic sector. Therefore, in making the decision to determine the marketing of BBM products, it must be oriented to the level of community needs based on purchasing power according to the average level of income of the community. Macro and micro decisions are important in marketing BBM. Because the price of fuel is regulated by the government in accordance with world crude oil market conditions. On this basis,smart marketing is needed [1].

Smart marketing is always oriented to the ability to compete for profit. On this basis, the consideration of buying product loyalty is absolutely considered by marketing practitioners. Loyalty is a guarantee of customers making repeated purchases, recommending purchase references, and showing positive responses to the products they buy. The point is loyalty will be present in the customer if the product has been trusted and is believed to not have a detrimental effect [2]. Loyalty is the ultimate goal of marketing activities to provide added value in marketing activities $[3,4]$.

Given the importance of this loyalty, government intervention and global economic conditions must be considered in making decisions to determine the marketing of BBM, because this marketing is in a sensitive area. Loyalty always arises and lasts when the customer feels the satisfaction of the purchase of the product he bought gives an appreciation that is a satisfied evaluation and does not complain about the evaluation of the product he bought. Satisfaction gives importance to one's loyalty.

The higher the level of loyalty, the more fulfilled customer satisfaction for the product bought [2]. On this basis, to measure customer satisfaction can be assessed from the size of the system of complaints and suggestions recorded, evaluating product user satisfaction surveys, using ghost shopping and creating relationships with customers both old and new to assess the product according to its appreciation [5].

Customer satisfaction and loyalty in marketing activities become a blueprint that must be addressed by developers or marketers to determine how much the real influence that causes satisfaction and loyalty has increased or decreased. For some initial observations related to Pertamina's products, it was identified that the company's image, service quality and price perception are priorities to be considered to determine satisfaction and loyalty increase or decrease.

The fact is that Pertamina's corporate image related to fuel oil (BBM) marketing has received a positive image in the community, especially with regard to the quality of products sold, services provided, company policies, company reputation and company marketing activities, 
which of course have been maintained, although this competition is often exposed. with tilted issues, especially those related to practices oil mafiathat allegedly damaged Pertamina's corporate image. The company's image is an important momentum to realize satisfaction and achieve customer loyalty [6].

Besides Pertamina customers assess the marketing activities implemented so far have not been optimal in accordance with the expected quality of service. That hope is not in accordance with the demands and needs desired. The fact is that customers often voice customer voice that Pertamina has not provided services tangible properly, because in an SPBU region it is not evenly distributed, lacks a sense of empathy in distributing fuel evenly because it is often found that gas stations are exhausted or empty at certain times, the level of reliability serving is still oriented to selling orders on the spot, lack of response to customer oriented does not limit the purchase of fuel and the low guarantee of services provided to household consumption customers and fishermen. The key to marketing success lies in the quality of service oriented to customer satisfaction and loyalty [7].

The issue of fuel prices is often mocked by oil speculators, especially the mafia who want to gain profits by breaking down or forcing the government to adopt policies to raise fuel prices. Of course pertamina in taking pricing must be oriented to demand-based prices, costs, profits and competition. For demand-based prices set skimming prices, penetration prices, prestige prices and price lining. Costbased prices are standard mark-up pricing, cost plus percentage of cost pricing, cost plus fixed fee pricing and experience curve pricing. Profit-based prices are target profit pricing, target return on sales pricing and target return on investment pricing. As well as price based competition in the form of customary pricing, above or below pricing, loss leader pricing and sealed bid pricing. Price considerations always follow market mechanisms and government policies. This is a frequent cause of unstable customer satisfaction and loyalty in the decision to purchase Pertamina products $[8,9]$.

\section{LITERATURE REVIEW}

There are five observed variables In this study, consisting of three exogenous variables and two endogenous variables. Exogenous variables in this study consisted of corporate image, service quality and price perception. While endogenous variables are intermediate variables, namely customer satisfaction and dependent variable, purchase loyalty

\section{A. Corporate image}

Corporate image refers to the theory of the formation of a corporate image [10] that to win product competition in realizing customer satisfaction and loyalty requires the formation of a corporate image. The company's image is built on: (1) the quality of the products produced; (2) services provided; (3) company policy; (4) company reputation; and (5) company marketing activities.

Corporate image is a consumer's perception of a corporate entity. This image will remain in a consumer's mind further affecting purchase behaviors or intentions. By means of the products, services and related information, consumers develop a subjective appraisal of a corporation, thus forming a corporate image. We believe that a positive corporate image can decrease uncertainty in consumer decision making and establish a high level of recognition among certain businesses [10]. Corporate image as a society's overall impression, including the interaction between physical and invisible elements. In summary, corporate image is an integrated perception that represents the degree to which consumers identify with a business [11.12].

$\mathrm{H}_{1 \mathrm{a}}$ : Corporate image directly has a positive and significant effect on Pertamina's customer satisfaction.

$\mathrm{H}_{1 \mathrm{~b}}$ : Corporate image directly has a positive and significant effect on purchase loyalty

$\mathrm{H}_{1 \mathrm{c}}$ : Corporate image through satisfaction has a positive and significant effect on purchase loyalty

\section{B. Service quality}

Service quality refers to service quality theory $[7,13]$ suggesting the concept of service quality that quality service is a consideration for customers to fulfill satisfaction and product purchase loyalty. The service quality is in the form of physical evidence, empathy, reliability, responsiveness and assurance.

$\mathrm{H}_{2 \mathrm{a}}$ : Service quality directly has a positive and significant effect on customer satisfaction in Pertamina

$\mathrm{H}_{2 \mathrm{~b}}$ : Service quality directly has a positive and significant effect on purchase loyalty

$\mathrm{H}_{2 \mathrm{c}}$ : Service quality through customer satisfaction has a positive and significant effect on purchase loyalty

\section{Price perception}

Price Perception refers to competition price theory [8] that product price competition depends on market mechanisms. Price perception in the form of competitive prices penetrated, runs according to the feasibility and stability of product prices.

$\mathrm{H}_{3 \mathrm{a}}$ : Perception of price directly has a positive and significant effect on Pertamina customer satisfaction.

$\mathrm{H}_{3 \mathrm{~b}}$ : Perception of price directly has a positive and significant effect on purchase loyalty

$\mathrm{H}_{3 \mathrm{c}}$ : Price perception through customer satisfaction has a positive and significant effect on purchase loyalty

\section{Customer satisfaction}

Satisfaction refers to the theory of customer satisfaction assessment, that there are four methods to measure customer satisfaction, namely considering the complaint and suggestion system, conducting a customer satisfaction survey, applying ghost shopping and contacting customers $[2,14]$.

\section{E. Purchase loyalty}

Building customer loyalty is a critical goal in business. Customer loyalty can be categorized into attitudinal and behavioral loyalty. Purchase loyalty empirically derives two distinct dimensions of the loyalty construct: active and passive loyalty. Active loyalty behaviors are those that require a conscious and deliberate effort to undertake, and are reflected in both purchase behavior and purchase intentions [15]. Purchase loyalty refers to the theory of loyalty assumptions $[3,16]$. that assesses loyal or non-loyal customers as seen from loyalty make regular repurchases, 
always recommending experience references to others for the product purchased and showing a positive response to the product offered.

$\mathrm{H}_{4}$ : Customer satisfaction directly has a positive and significant effect on purchase loyalty

\section{RESEARCH METHOD}

This study is designed to answer the problems that have been formulated and the objectives to be achieved and test the hypothesis. The location of the study was conducted at Pertamina companies in South Sulawesi Province as the object of research to see the effect of corporate image, service quality and price perception on customer satisfaction and purchase loyalty of Pertamina products. Research time is scheduled for three months from December to November 2019. There are two types of research, namely quantitative and qualitative research. Sources of data in this study consisted of primary and secondary data. Data collection techniques (instruments) used were observation, questionnaire, interview and documentation.

The population in this study are customers who use Pertamina products in the area of South Sulawesi Province. Determination of the sample is done using the quota sampling method [17]. The researcher determined purposely as many as 5,540 customers, then the researchers used 5\% quota sampling as research respondents. Determination of sample quota researchers conducted by accidental sampling according to the wishes of customers who were willing to become respondents, so that a total sample of 5,540 customers was obtained, and after going through the 5\% quota sampling method 277 respondents were obtained. Data analysis techniques used in explaining the phenomena in this study are descriptive statistical analysis techniques and Structural Equation Modeling (SEM) analysis.

\section{RESEARCH RESUlTS}

The first model testing was grouped into exogenous variables and endogenous variables. Exogenous variables are variables whose values are determined outside the model. Whereas endogenous variables are variables whose value is determined through equations or from established relationship models. Included in the group of exogenous variables is the measurement of corporate image, service quality and price perception, while those classified as endogenous variables are customer satisfaction and product purchase loyalty. The model is said to be good when the development of hypothetical models is theoretically supported by empirical data. Evaluation of the eight criteria model shows a goodness of fit indices seen the value of chisquare still great and looks some criteria are not in accordance with values, cut-off the specified so that a modification of the model by performing the correlation between the error indicator according to the instructions of the modification indices.

The model test results are evaluated based on the goodness of fit indices [18] in the Table 1 with the model criteria and their critical values that have the suitability of the data presented.

TABLE I: GOODNESS OF FIT INDICES OVERALL MODEL

\begin{tabular}{cccc}
\hline \hline Goodness of fit indices & Cut-off value & First Model & $\begin{array}{c}\text { Final } \\
\text { Model }\end{array}$ \\
\hline Chi_Square & Small & 378.817 & 100.440 \\
Probability & $\geq 0: 05$ & 0.000 & 0.191 \\
CMIN / DF & $\leq 2: 00$ & 3.352 & 1.129 \\
RMSEA & $\leq 0: 08$ & 0.092 & 0.022 \\
GFI & $\geq 0.90$ & 0.858 & 0.959 \\
AGFI & $\geq 0.90$ & 0.808 & 0.929 \\
TLI & $\geq 0.94$ & 0.785 & 0.988 \\
CFI & $\geq 0.94$ & 0.821 & 0.992 \\
Degrees of freedom & 113 & 89 & \\
\hline \hline
\end{tabular}

The results of the evaluation model for early stage shows the eight criteria of goodness of fit indices do not meet the criteria for a cut-off value [19], starting from the value of Chi-Square, probability, CMIN / df, RMSEA, GFI, AGFI , TLI and CFI, so that the model needs to be modified according to the instructions of the modification indices. Modification Indices (MI) is a calculation to make changes to numbers, where the numbers below indicate the minimum value of the chi-square that will go down if the corresponding variables are connected. After modifying the model, the final stage shows that the eight criteria for goodness of fit indices meet the cut-off values, so the model is said to be in accordance with the criteria for goodness of fit indices to be analyzed.

Based on the empirical model proposed in this study, testing of hypotheses can be tested through path coefficient testing on structural equation models. Table 2 is testing the hypothesis by looking at the p-value, if the p-value $=<0.05$ then the relationship between variables is significant. It also explains the direct effect means that there is a positive influence directly between variables, the indirect effect means that there is a positive influence indirectly between the variables, and the total effect that is the accumulation of direct effects and indirectly. The test results are presented in following the Table:

\begin{tabular}{|c|c|c|}
\hline No. & Causality effect & P-value \\
\hline $\mathrm{H}_{1 \mathrm{a}}$ & $\begin{array}{l}\text { Corporate Image }\left(\mathrm{X}_{1}\right) \rightarrow \text { Customer } \\
\text { Satisfaction }(\mathrm{Y})\end{array}$ & 0,000 \\
\hline $\mathrm{H}_{1 \mathrm{~b}}$ & $\begin{array}{l}\text { Corporate Image }\left(\mathrm{X}_{1}\right) \rightarrow \text { purchase } \\
\text { loyalty }(\mathrm{Z})\end{array}$ & 0,000 \\
\hline $\mathrm{H}_{1 \mathrm{c}}$ & $\begin{array}{l}\text { Corporate Image }\left(\mathrm{X}_{1}\right) \rightarrow \text { Customer } \\
\text { Satisfaction }(\mathrm{Y}) \rightarrow \text { purchase } \\
\text { loyalty }(\mathrm{Z})\end{array}$ & 0,000 \\
\hline $\mathrm{H}_{2 \mathrm{a}}$ & $\begin{array}{l}\text { Service quality }\left(\mathrm{X}_{2}\right) \rightarrow \text { Customer } \\
\text { Satisfaction }(\mathrm{Y})\end{array}$ & 0.023 \\
\hline $\mathrm{H}_{2 b}$ & $\begin{array}{l}\text { Service quality }\left(\mathrm{X}_{2}\right) \rightarrow \text { purchase } \\
\text { loyalty }(\mathrm{Z})\end{array}$ & 0.011 \\
\hline $\mathrm{H}_{2 \mathrm{c}}$ & $\begin{array}{l}\text { Service quality }\left(\mathrm{X}_{2}\right) \rightarrow \text { Customer } \\
\text { Satisfaction }(\mathrm{Y}) \rightarrow \text { purchase } \\
\text { loyalty }(\mathrm{Z})\end{array}$ & 0.005 \\
\hline $\mathrm{H}_{3 \mathrm{a}}$ & $\begin{array}{l}\text { Price Perception }\left(\mathrm{X}_{3}\right) \rightarrow \text { Customer } \\
\text { Satisfaction }(\mathrm{Y})\end{array}$ & 0.014 \\
\hline $\mathrm{H}_{3 \mathrm{~b}}$ & $\begin{array}{l}\text { Price Perception }\left(\mathrm{X}_{3}\right) \rightarrow \text { purchase } \\
\text { loyalty }(\mathrm{Z})\end{array}$ & 0.033 \\
\hline $\mathrm{H}_{3 \mathrm{c}}$ & $\begin{array}{l}\text { Price Perception }\left(\mathrm{X}_{3}\right) \rightarrow \text { Customer } \\
\text { Satisfaction }(\mathrm{Y}) \rightarrow \text { purchase } \\
\text { loyalty }(\mathrm{Z})\end{array}$ & 0.132 \\
\hline $\mathrm{H}_{4}$ & $\begin{array}{l}\text { Customer Satisfaction }(\mathrm{Y}) \quad \rightarrow \\
\text { purchase loyalty }(\mathrm{Z})\end{array}$ & 0,000 \\
\hline
\end{tabular}

The p-value results on the effect of indirect effects of independent variables through intermediate variables on the dependent variable in SEM analysis shows a positive and 
significant effect, then to prove the effect The indirect test is then performed a Sobel test (computing Sobel Test of Mediation for Baron \& Kenny Approach) with the following calculation results:

TABLE III: SOBEL TEST EFFECT OF CORPORATE IMAGE $\left(\mathrm{X}_{1}\right) \rightarrow$ CUSTOMER SATISFACTION $(\mathrm{Y}) \rightarrow$ PURCHASE LOYALTY $(\mathrm{Z})$

\begin{tabular}{cc}
\hline SATISFACTION $(\mathrm{Y}) \rightarrow$ PURCHASE LOYALTY $(\mathrm{Z})$ \\
\hline Results & Value \\
\hline Indirect Effect $(\mathrm{a} * \mathrm{~b})$ & 0.364 \\
Sobel's SE $=\sqrt{ }\left[\left(\mathrm{a}^{*} \mathrm{SE} b\right)+\left(b^{*} \mathrm{SEa}\right)^{2}\right]$ & 0.105 \\
$\mathrm{Z}=$ Indirect Effect + Sobel's SE & 3.483 \\
$P$ & 0.000 \\
Standardized Indirect Effect $=\left(\beta^{*} \beta_{b}\right)$ & 0.268 \\
Portion of $(\mathrm{X} \rightarrow \mathrm{Y})$ due to $\mathrm{M}=\left(\mathrm{c}-\mathrm{c}^{\prime}\right) / \mathrm{c}$ & $100.0 \%$ \\
\hline \hline
\end{tabular}

The Corporate image indirectly through customer satisfaction has a positive and significant effect on product purchase loyalty with the Sobel Standardized Indirect Effect test of 0.268 with $p$-value $=0.000<0.05$.

TABLE IV: SOBEL TEST EFFECT OF SERVICE QUALITY $\left(\mathrm{X}_{2}\right) \rightarrow$ CUSTOMER SATISFACTION $(\mathrm{Y}) \rightarrow$ PURCHASE LOYALTY $(\mathrm{Z})$

\begin{tabular}{cc} 
SATISFACTION $(\mathrm{Y}) \rightarrow$ PURCHASE LOYALTY $(\mathrm{Z})$ \\
\hline \hline Results & Value \\
\hline Indirect Effect $(\mathrm{a} * \mathrm{~b})$ & 0.229 \\
Sobel's SE $=\sqrt{ }\left[\left(\mathrm{a}^{*} \mathrm{SE} b\right)+\left(b^{*} \mathrm{SEa}\right)^{2}\right]$ & 0.081 \\
$\mathrm{Z}=$ Indirect Effect + Sobel's SE & 2.811 \\
$P$ & 0.005 \\
Standardized Indirect Effect $=\left(\beta^{*}{ }^{*} \beta_{b}\right)$ & 0.206 \\
Portion of $(\mathrm{X} \rightarrow \mathrm{Y})$ due to $\mathrm{M}=\left(\mathrm{c}-\mathrm{c}^{\prime}\right) / \mathrm{c}$ & $100.0 \%$ \\
\hline \hline
\end{tabular}

Service quality indirectly through customer satisfaction has a positive and significant effect on purchase loyalty with Sobel Standardized Indirect Effect test, the results of 0.206 with p-value $=0.005<0.05$.

TABLE V: SOBEL TEST EFFECT OF PRICE PERCEPTION $\left(\mathrm{X}_{3}\right) \rightarrow$ CUSTOMER

\begin{tabular}{cc} 
SATISFACTION $(\mathrm{Y}) \rightarrow$ PURCHASE LOYALTY $(\mathrm{Z})$ \\
\hline \hline Results & Value \\
\hline Indirect Effect $\left(\mathrm{a}^{*} \mathrm{~b}\right)$ & 0.153 \\
Sobel's SE $=\sqrt{ }\left[\left(\mathrm{a}^{*} \mathrm{SE} b\right)+\left(b^{*} \mathrm{SEa}\right)^{2}\right]$ & 0.102 \\
$\mathrm{Z}=$ Indirect Effect + Sobel's SE & 1.507 \\
$P$ & 0.132 \\
Standardized Indirect Effect $=\left(\beta_{a}{ }^{*} \beta_{b}\right)$ & 0.119 \\
Portion of $(\mathrm{X} \rightarrow \mathrm{Y})$ due to $\mathrm{M}=\left(\mathrm{c}-\mathrm{c}^{\prime}\right) / \mathrm{c}$ & $100.0 \%$ \\
\hline \hline
\end{tabular}

Price perception indirectly through customer satisfaction has a positive and insignificant effect on product purchase loyalty with Sobel standardized indirect effect test, the results of 0.119 with $p$-value $=0.132>0.05$.

The overall model of the seven direct paths and the three indirect pathways were hypothesized, based on the results of the SEM AMOS analysis giving a positive and significant effect. While the results of the Sobel test analysis for the indirect effect showed price perception (X3) through customer satisfaction had a positive and not significant effect on product purchase loyalty. Based on the results obtained, it can be stated that:

1. Corporate image has a positive and significant direct effect on customer satisfaction with $\mathrm{p}$ - value $=0.000$ $<0.05$ and coefficient value of 0.591 , this coefficient indicates that the image of the company shown is right and gives satisfaction to the customer.

2. Service quality has a positive and significant direct effect on customer satisfaction with $\mathrm{p}$-value $=0.023$
$<0.05$ and coefficient values of 0.455 , this coefficient indicates that the quality of service is good and gives satisfaction to customers.

3. Price perception has a positive and significant direct effect on customer satisfaction with $\mathrm{p}$ - value $=0.014$ $<0.05$ and coefficient values of 0.262 , this coefficient indicates that the perception of the price set is appropriate and gives satisfaction to the customer.

4. Corporate image has a positive and significant direct effect on product purchase loyalty with $\mathrm{p}$-value $=0,000$ $<0.05$ and coefficient value of 0.395 , this coefficient indicates that the company's image determines an increase in product purchase loyalty.

5. Service quality has a positive and significant direct effect on product purchase loyalty with $\mathrm{p}$ - value $=0.011$ $<0.05$ and coefficient values of 0.314 , this coefficient indicates that service quality determines an increase in product purchase loyalty.

6. Price perception has a positive and significant direct effect on product purchase loyalty with $\mathrm{p}$-value $=0.033$ $<0.05$ and coefficient value of 0.295 , this coefficient indicates that the perception of a stable price determines an increase in purchase loyalty

7. Customer satisfaction has a positive and significant direct effect on product purchase loyalty with p-value $=$ $0.000<0.05$ and coefficient value of 0.569 , this coefficient indicates that the achievement of customer satisfaction affects the increase in purchase loyalty.

8. Corporate image through customer satisfaction has a positive and significant indirect effect on product purchase loyalty with a coefficient value of AMOS, analysis indirect effect of 0.185 . While the results of calculations through the sobel test obtained by 0.268 with a significance level of $\mathrm{p}$-value $=0.000<0.05$ (significant), proves that the corporate image shown has provided customer satisfaction, and indirectly has a significant effect on increasing product purchase loyalty.

9. Service quality through customer satisfaction has a positive and significant indirect effect on product purchase loyalty with a coefficient value of AMOS analysis indirect effect of 0.178 . While the results of calculations through the sobel test obtained by 0.206 with a significance level of the p- value $=0.005<0.05$ (significant), proving that the quality of service applied has given satisfaction to customers, and indirectly has a significant effect on increasing product purchase loyalty.

10. Price perception through customer satisfaction has a positive and significant indirect effect on product purchase loyalty with a coefficient value of AMOS analysis indirect effect of 0.169 with a level significant of $0.033<0.05$ (significant). But the results of calculations through the sobel test obtained by 0.119 with a significance level of the $p$-value $=0.132>0.05$ (not significant), proving that the price perception of Pertamina products in general has given satisfaction to customers but not significantly to product purchase loyalty due to the price of the first product sometimes increases depending on the prevailing inflation value.

Analysis of direct effect, indirect effect and total effects between variables in the model, was used to compare the effect of each variable constructs. The direct effect is the 
coefficient of all coefficient lines with one end of the arrow, while the indirect effect is the effect that arises through an intervening variable while the total effect is the effect of various relationships.

\section{CONCLUSION}

Based on the analysis of the results and the discussion concluded as follows: (1) The company's image has a positive and significant effect on customer satisfaction. Product impressions increase customer satisfaction; (2) Service quality has a positive and significant effect on customer satisfaction, service quality makes customers satisfied using the product; (3) Price perception has a positive and significant effect on customer satisfaction. Stable product pricing gives satisfaction to customers; (4) The company's image has a positive and significant effect on product purchase loyalty. A good image builds repeat buying product loyalty, provides references and positive responses; (5) Service quality has a positive and significant effect on product purchase loyalty in accordance with affordability; (6) Price perception has a positive and significant effect on product purchase loyalty, price becomes a consideration in determining the frequency of customer purchases; (7) Customer satisfaction has a positive and significant effect on product purchase loyalty. Feelings of pleasure using the product as an actualization of the attitude of customer loyalty; (8) Corporate image through satisfaction has a positive and significant effect on product purchase loyalty. Customers want products that are highly memorable and satisfying; (9) Quality of service through satisfaction has a positive and significant effect on product purchase loyalty. Actualization of services quality is able to provide satisfaction for each service, so that customers remain consistent to use the product purchased; and (10) Price perception through satisfaction has a positive and not significant effect on product purchase loyalty. This shows that price volatility is very disruptive to market mechanisms in realizing customer satisfaction and the level of product loyalty. Each of these implementations can increase the possibility of repurchase intentions; however, enhancing corporate image is an effective way to stimulate consumer purchase intentions and behavior. It is far-fetched to expect a company to stimulate purchase behaviors or intentions only through the enhancement of corporate image

\section{REFERENCES}

[1] Kurtubi, (2019). Product and Service Marketing. Pustakajaya Publisher, Jakarta.

[2] Kotler, P. (2015). Marketing management: the millennium edition (Vol. 199). Upper Saddle River, NJ: Prentice Hall.

[3] Griffin, Peterson, (2015). The Image Important for Business Company. Published by John Wiley and Sons, New York.

[4] Warokka, A., Sjahruddin, H., Sriyanto, S., Noerhartati, E., Saddhono, K. (2020). Digital marketing support and business development using online marketing tools: An experimental analysis. International Journal of Psychosocial Rehabilitation. Volume: 24. Issues: 1. 11811188

[5] Boyest, Jacob, (2018). Marketing and Market Image. Published by John Wiley and Sons, New York

[6] Wilson, Domascus. (2017). Marketing Competitive and Performance. Prentice Hall Cliffs, New Jersey.

[7] Parasuraman, A. Valerie. (2015). Delivering Quality Service. The Free Press, New York. (Translated by Sutanto).

[8] Bukhari, Alma. (2016). Marketing Services and Products. Rineka Cipta Publisher, Jakarta

[9] Warokka, A., Sjahruddin, H., Reni, A., Baihaqi, Nasution, E.S. (2020). Data mining, financial performance and financial decisions on business: Evidence from digital marketing.. International Journal of Psychosocial Rehabilitation. Volume: 24. Issues: 1. 1160-1168.

[10] Kerby, R.H. (2014). Principles of Image Image Marketing. $10^{\text {th }}$ ed. Published of Prentice Hall, New Jersey.

[11] Robertson, T. S., \& Gatignon, H. (1986). Competitive effects on technology diffusion. Journal of Marketing, 50(3), 1-12.

[12] Bloemer, J. M. M., \& Odekerken-Schröder, G. J. (2002). Store satisfaction and store loyalty explained by customer-and store related factors.

[13] Mokhtar, S., \& Sjahruddin, H. (2019). An examination of the relationships between customer relationship management quality, service quality, customer satisfaction and customer loyalty: The case of five star hotels. Advances in the Social Sciences Research Journal, $6(2)$.

[14] Themba, OS, Razak, N., \& Sjahruddin, H. (2019). Increasing customers' loyalty. The contribution of marketing strategy, service quality and customer satisfaction. Archives of Business Research, 7 (2).

[15] Ganesh, J., Arnold, M. J., \& Reynolds, K. E. (2000). Understanding the customer base of service providers: an examination of the differences between switchers and stayers. Journal of marketing, 64(3), 65-87.

[16] Razak, N., Themba, OS, \& Sjahruddin, H. (2019). Brand awareness as predictors of repurchase intention: Brand attitude as a moderator. Advances in the Social Sciences Research Journal, 6 (2).

[17] Hair Jr, J. F., \& Lukas, B. (2014). Marketing research. McGraw-Hill Education Australia.

[18] Hair, J. F., Black, W. C., Babin, B. J., Anderson, R. E., \& Tatham, R. L. (2006). Multivariate data analysis (Vol. 6). Pearson Prentice Hall, Upper Saddle River.

[19] Yakub, A., Sessu, A., Sjahruddin, H., \&, Haryono. (2020). Exploring the Nexus between Foreign Aid, Corruption and Economic Growth in ASEAN Countries Andi Yakuba*, Andi Sessub, Herman Sjahruddinc, Haryono. The International Journal of Innovation, Creativity and Change. Volume 11, Issue 2 